\title{
Leiolima iberica, a new harvestman genus and species from the Iberian Peninsula (Arachnida, Opiliones, Sclerosomatidae)
}

\author{
Carlos E. PRIETO ${ }^{1, *} \&$ Hay WIJNHOVEN ${ }^{2}$ \\ ${ }^{1}$ Departamento de Zoología y Biología Celular Animal, Universidad del País Vasco \\ (UPV / EHU), PO Box 644, E-48080 Bilbao, Spain. \\ ${ }^{2}$ Groesbeeksedwarsweg 300, NL-6521 DW Nijmegen, Netherlands. \\ *Corresponding author: carlos.prieto@ehu.eus \\ 2Email: hayw@xs4all.nl \\ ${ }^{1}$ urn:lsid:zoobank.org:author:CAC20D21-78FF-4B8A-8023-F06A06EA031F \\ ${ }^{2}$ urn:lsid:zoobank.org:author:484CDCCE-5F82-4D84-B9BB-BE7AE7145AD7
}

\begin{abstract}
Recent studies have shown that the speciose Holarctic genera of Leiobunum C.L. Koch, 1839 and Nelima Roewer, 1910 are polyphyletic taxa, and therefore, the traditional diagnostic characters for these European genera of Leiobuninae Banks, 1893 (respectively, the presence or absence of tubercle rows on leg coxae) are unsuitable. We present the description of Leiolima iberica gen. et sp. nov., a new endemic harvestman from the north-western part of the Iberian Peninsula. The newly established genus shows intermediate characters between Leiobunum and Nelima. In addition, the new genus is characterized by shorter legs compared to Leiobunum and the presence of trichomes on all leg femora and pedipalpal patellae, a structure that is absent in all other western Palearctic genera of the subfamily Leiobuninae.
\end{abstract}

Keywords. Leiolima new genus, Leiolima iberica new species, Portugal, Spain, trichomes.

Prieto C.E. \& Wijnhoven H. 2020. Leiolima iberica, a new harvestman genus and species from the Iberian Peninsula (Arachnida, Opiliones, Sclerosomatidae). European Journal of Taxonomy 609: 1-20.

https://doi.org/10.5852/ejt.2020.609

\section{Introduction}

The subfamily Leiobuninae Banks, 1893 is represented by three genera in Europe, Leiobunum C.L. Koch, 1839, Cosmobunus Simon, 1879 and Nelima Roewer, 1910 (Martens 1978; Rambla 1970). Geographically close to Europe are Microliobunum Roewer, 1912, with its two species from Lebanon and SE-Turkey, and the monotypic Goasheer Snegovaya et al., 2018 erected for Microliobunum iranum Roewer, 1952 (Kurt 2018; Snegovaya et al. 2018). Cosmobunus is also a monotypic genus, with Cosmobunus granarius Lucas, 1846 ranging from northern Algeria and Morocco to Catalonia NE-Spain, although it has recently been proposed that a fossil Miocene specimen from Spain belongs to the genus Cosmobunus (Palencia et al. 2019). Cosmobunus granarius is similar to Leiobunum, but 
easily diagnosed by its having a smooth pedipalpal claw, a rough sclerotized dorsal surface and a broad yellowish longitudinal band (Rambla 1970).

Currently, the species of Nelima are separated from Leiobunum merely by a negative criterion: the leg coxae lack any row of tubercles, whereas the species of Leiobunum are defined as having at least one row (Martens 1978). Martens $(1969,1978)$ has already mentioned that this single discriminating feature is not sufficient to reveal true phylogenetic relationships, since penial morphology is not even taken into account. Martens \& Schonhöfer (2016) provide a recent example demonstrating this problem by creating a group of species around Leiobunum rupestre (Herbst, 1799) for four European species, including L. apenninicum (Martens, 1969), originally described under Nelima. In fact, an extensive molecular analysis of the New World complex of 'Leiobunum/Nelima' (Hedin et al. 2012) has clearly demonstrated that the classical taxonomical approach is highly superficial and that the entire group (Sclerosomatidae) needs comprehensive revisions. In that paper, Gyas titanus Simon, 1879 (Sclerosomatidae) belonged to the clade of Phalangiidae Simon, 1879, thus suggesting a new placement for the subfamily Gyinae Šilhavý, 1946, while the remaining Sclerosomatidae were recovered as a monophyletic group. Within this clade, the seven included European taxa (three Leiobunum spp., three Nelima spp. and Astrobunus grallator Simon, 1879, but no species of Cosmobunus) were recovered in basal positions, with the exception of Nelima doriae (Canestrini, 1871), which was grouped with some New World Gagrellinae Thorell, 1889. However, neither Leiobunum nor Nelima, two genera with Holarctic ranges, have been recovered as monophyletic groups. Interestingly, the two European taxa included in the combined analysis ( $N$. doriae and Astrobunus) were proven to form a clade, although being placed in different subfamilies, which is a perfect demonstration of the title by Hedin et al. (2012), that is, in this group "geography is better than taxonomy" in the prediction of phylogeny.

The Iberian Peninsula is known for its high level of endemism (Prieto 2003). So far, eight species of Leiobunum and five species of Nelima have been reported from the region (Martens 1969; Prieto \& Fernández 2007; Prieto 2008; Prieto \& Wijnhoven 2017), of which six and two species, respectively, are endemic. Several representatives of Leiobuninae from the Iberian Peninsula await descriptions (Prieto 2008).

In this contribution, we present a new species of Leiobuninae from Northern Spain/Portugal, whose general appearance is reminiscent of that of Nelima. However, since it also has distinct coxal tubercle rows, by definition, we ought to use the generic name Leiobunum for this taxon. To face this conflictive situation, we introduce the name Leiolima gen. nov., being aware of the fact that the European Sclerosomatidae should be thoroughly revised. The species was first mentioned and figured by Prieto (2008: fig. 10) as Leiobunum sp. nov.

\section{Material and methods}

\section{Institutional abbreviations}

$\begin{aligned} \text { AMNH = } & \text { American Museum of Natural History, New York, USA } \\ \text { CHW }= & \text { Collection Hay Wijnhoven, Nijmegen, the Netherlands } \\ \text { CJM }= & \text { Collection Jochen Martens, Mainz, Germany } \\ \text { MNCN = } & \text { Museo Nacional de Ciencias Naturales (CSIC), Madrid, Spain } \\ \text { MNHN = } & \text { Muséum national d'histoire naturelle, Paris, France } \\ \text { Naturalis = } & \text { Naturalis Biodiversity Center, Leiden, the Netherlands } \\ \text { SMF = } & \text { Senckenberg Natural History Museum, Frankfurt am Main, Germany } \\ \text { ZUPV = } & \text { Departamento de Zoología y Biología Celular Animal, University of the Basque Country } \\ & \text { (UPV / EHU), Leioa, Bizkaia, Spain }\end{aligned}$


Prieto C.E. \& Wijnhoven H., Leiolima (Opiliones, Sclerosomatidae), a new genus from Iberia

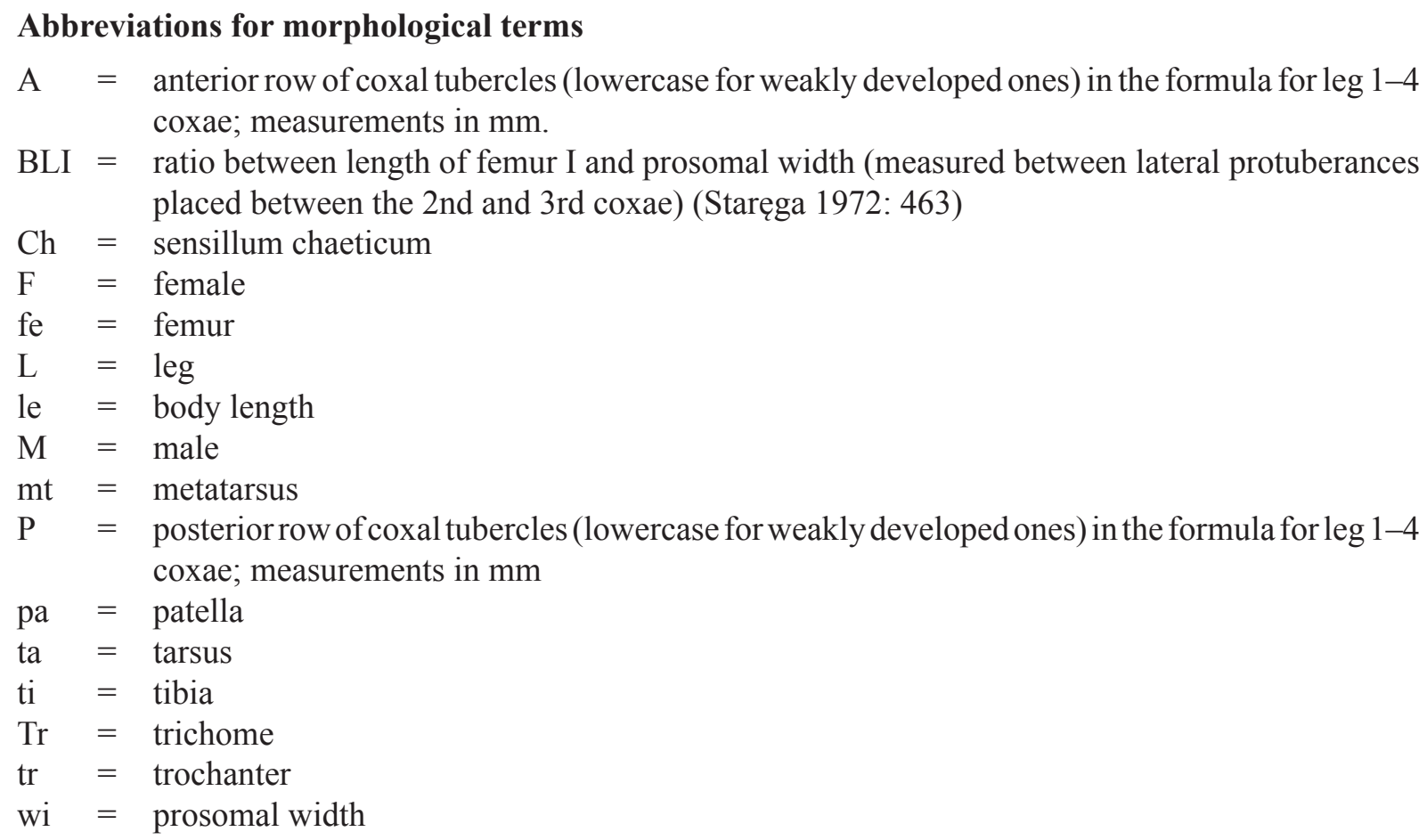

\section{Results}

Taxonomy

Class Arachnida Lamarck, 1801

Order Opiliones Sundevall, 1833

Family Sclerosomatidae Simon, 1879

Subfamily Leiobuninae Banks, 1893

Leiolima gen. nov. urn:1sid:zoobank.org:act:D808528C-9131-4A73-B0B5-48DA9132A183

\section{Type species}

Leiolima iberica gen. et sp. nov.

\section{Diagnosis}

A genus of the subfamily Leiobuninae having the following combination of characters: prosomal shield fully granulated; supra-cheliceral lamellae with two cylindrical, apically granulated protuberances; ozopores being rounded and minute; ocularium is deep black, granulated, canaliculate and does not tilt backwards; cephalothorax with a median raised area in front of ocularium; opisthosoma densely covered with coarse granules; saddle as paramedian pairs of diffuse patches; leg coxae margins with short tubercle rows, except on rear margin of third leg coxae; trochanter concolorous with coxae; legs of medium length, brownish, with silvery spots on dorsal sides; leg femora and patellae covered with trichomes; tibia II with pseudoarticulations; pedipalpal patella, tibia and tarsus covered with trichomes; pedipalpal male tarsus without ventral row of microdenticles, claw pectinate; slender penis, with broadened alate portion; ventral membranes reaching base of glans, further distal from the dorsal membranes.

This genus can easily be differentiated from the three currently accepted European genera of Leiobuninae. The monotypic Cosmobunus presents a smooth tarsal claw, large body size and long legs (males 
with BLI $>3$ ), opisthosomal sternites with denticle rows, and a conspicuous, lighter and broad medial stripe (contrasting with a dark lateral pattern). The European-Maghrebian species of the Holarctic speciose genus Leiobunum, which include the type species L. rotundum (Latreille, 1798), have very long legs (males with BLI $>3$ ) and an ocularium of variable color; the absence of trichomes on leg femora and patellae is the major character that distinguishes it from Leiolima. Like Leiobunum, Nelima is another Holarctic speciose genus with several European-Maghrebian species, including the type species Nelima silvatica (Simon, 1879); the absence of tubercle rows along the margins of the leg coxae is the main diagnostic feature.

\title{
Etymology
}

The generic epithet is a combination of the generic names Leiobunum and Nelima, and the gender is feminine.

\section{Key to the European genera of Leiobuninae}

1. Pedipalpal claws smooth. Opisthosomal sternites with transversal rows of granules

Cosmobunus Simon, 1879

- Pedipalpal claws pectinate (Fig. 5B). Opisthosomal sternites smooth

2. All leg coxae margins without tubercle rows

Nelima Roewer, 1910

- Some, at least one, leg coxae margins with tubercle rows 3

3. Leg femora covered with trichomes (Fig. 3A, D). Legs of medium length (males with BLI<2) ......

- Leg femora with 'sensilla chaetica' only (Fig. 3C, F). Long legs (males with BLI $>3$ )

Leiolima gen. nov.

Leiobunum C.L. Koch, 1839

\author{
Leiolima iberica gen. et sp. nov. \\ urn:1sid:zoobank.org:act:AFA32744-CAE4-4DF0-88FC-5122775787E1
}

Figs 1-10

Leiobunum sp. - Prieto 2008: fig. 10.

\section{Diagnosis}

Same as for genus.

Etymology

The specific epithet refers to its supposed endemicity for the Iberian Peninsula.

\section{Type material}

Holotype

SPAIN - O' León Prov., San Feliz de las Lavanderas; $42.6869^{\circ}$ N, $5.9765^{\circ}$ W; 1182 m a.s.1.; 12 Oct. 2006; C. Prieto and K. Altonaga leg.; pitfall traps; MNCN 20.02/17372.

\section{Paratypes}

SPAIN - León Prov. 1 ô, 1 or; same data as for holotype; MNCN 20.02/17373 to $17374 \bullet 2 \hat{\jmath}$; ; same

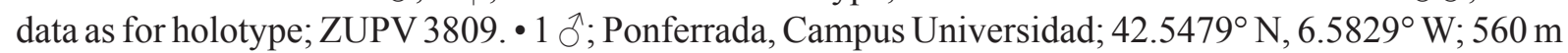
a.s.1.; 13 Oct. 2006; C. Prieto leg.; grasses; ZUPV $3821 \bullet 1$ ऊ̊; Robledo de la Valduerna; $42.3270^{\circ} \mathrm{N}$, 6.0696 ${ }^{\circ}$ W; 820 m a.s.1.; 8 Nov. 1988; K. Altonaga and R. Gorrotxategi leg.; riverside; ZUPV 1373 •

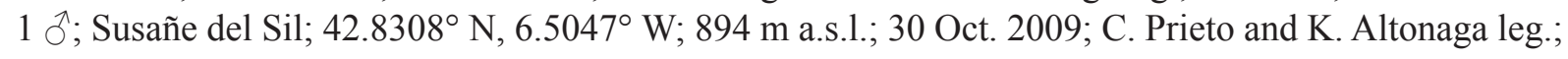


Prieto C.E. \& Wijnhoven H., Leiolima (Opiliones, Sclerosomatidae), a new genus from Iberia

ruderal, grass; ZUPV 4261 at CHW. - Ávila Prov.• 1 q; Piedrahita, Eta.Virgen de la Vega; $40.4876^{\circ}$ N, 5.3303 ${ }^{\circ}$ W; $1000 \mathrm{~m}$ a.s.1.; 22 Sep. 1987; K. Altonaga and A.I. Puente leg.; ZUPV 1446. - Salamanca

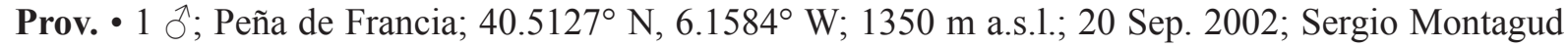
leg.; pasture, pinewood; ZUPV 3279. - Zamora Prov. 2 o o ô; Cubelo; $42.0982^{\circ} \mathrm{N}, 6.6509^{\circ} \mathrm{W} ; 1000 \mathrm{~m}$ a.s.1.; 9 Nov. 1988; K. Altonaga and R. Gorrotxategi leg.; orchards, oaks; ZUPV $1471 ・ 1$ ○े; Lubián; $42.0332^{\circ} \mathrm{N}, 6.9239^{\circ} \mathrm{W} ; 1030 \mathrm{~m}$ a.s.l.; 9 Nov. 1988; K. Altonaga and R. Gorrotxategi leg.; pasture, chestnuts; ZUPV $1076 \bullet 1$ ○ं; Tabara; $41.8509^{\circ}$ N, $5.9880^{\circ}$ W; 790 m a.s.1.; 9 Nov. 1988; K. Altonaga and R. Gorrotxategi leg.; pasture, poplars; ZUPV 1378.

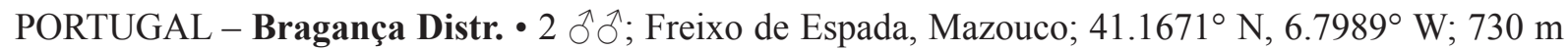
a.s.l.; 7 Feb. 2001; Pedro Cardoso leg.; Cistus, Genista; ZUPV 3324 • 1 q; Freixo de Espada, Palao; 41.1261 ${ }^{\circ}$ N, $6.8217^{\circ}$ W; 630 m a.s.1.; 10 Oct. 2001; Pedro Cardoso leg.; ZUPV $5001 \bullet 2$ o $O$; Freixo de Espada, Picotino; $41.2051^{\circ}$ N, $6.7619^{\circ}$ W; 740 m a.s.1.; 7 Feb. 2001; Pedro Cardoso leg.; ZUPV 5000 • 2 ते $\hat{0}, 1$ क; same collection data as for preceding; 21 Feb. 2001; Pedro Cardoso leg.; pinewood; ZUPV $3330 \bullet 3 \overbrace{}^{\lambda}$; same collection data as for preceding; CHW • 1 ते; Malhadas; $41.5429^{\circ} \mathrm{N}, 6.3205^{\circ} \mathrm{W}$; 740 m a.s.l.; 10 Nov. 1988; K. Altonaga and R. Gorrotxategi leg.; pasture, ash; ZUPV 1648 - 1 \%; Mogadouro, Algozinho; 41.3046 ${ }^{\circ} \mathrm{N}, 6.5590^{\circ} \mathrm{W} ; 620 \mathrm{~m}$ a.s.1.; 21 Feb. 2001; Pedro Cardoso leg.;

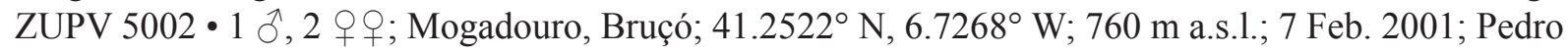

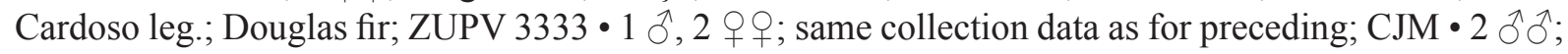
Porrais; $41.400^{\circ} \mathrm{N}, 6.805^{\circ} \mathrm{W} ; 360 \mathrm{~m}$ a.s.1.; 10 Nov. 1988; K. Altonaga and R. Gorrotxategi leg.; ruderal;
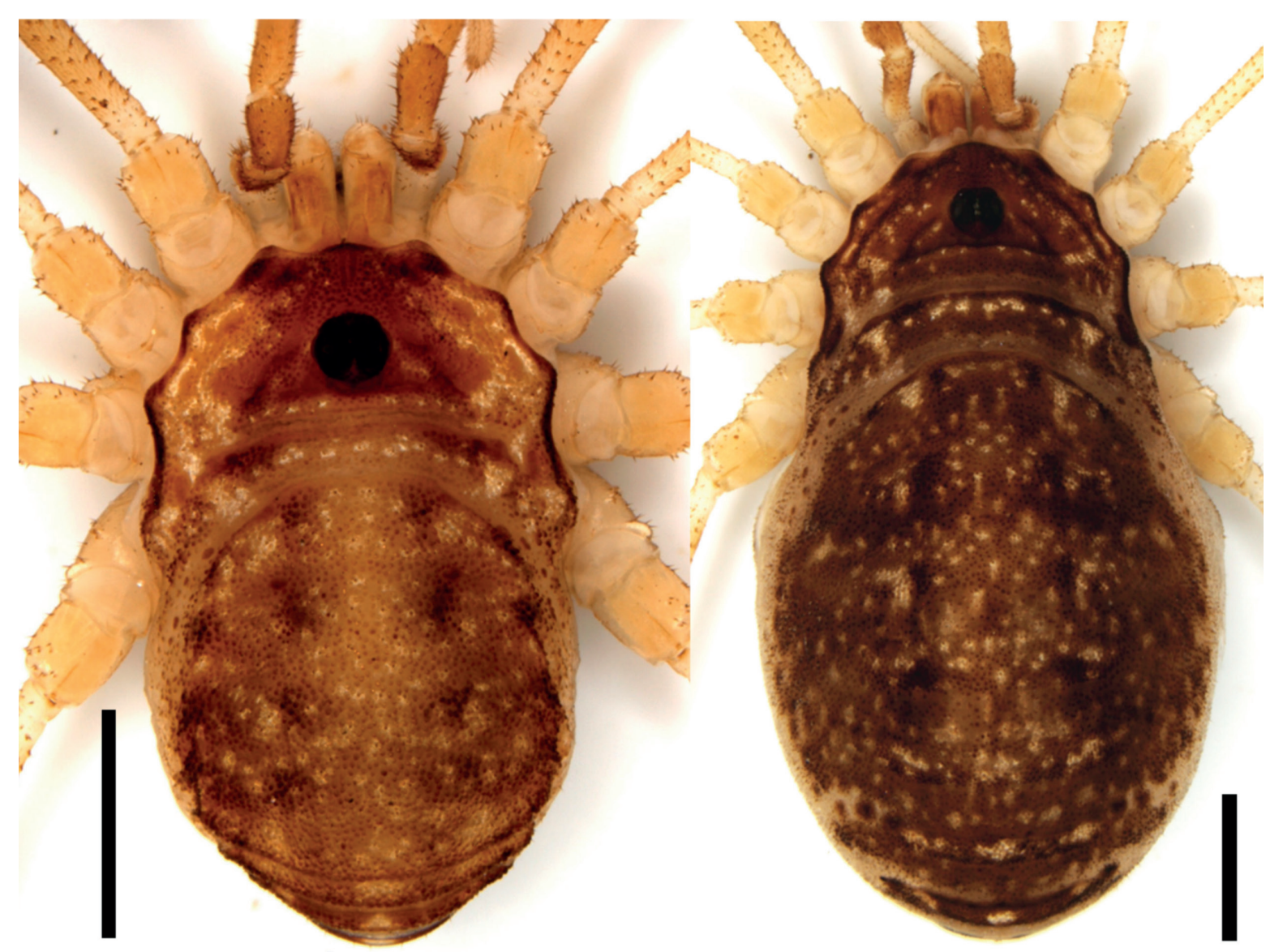

Fig. 1. Leiolima iberica gen. et sp. nov. Dorsal view of the male holotype (MNCN 20.02/17372) (left, body length $3.15 \mathrm{~mm}$ ) and a female paratype (MNCN 20.02/17374) (right, body length $5.58 \mathrm{~mm}$ ). Scale bars: $1 \mathrm{~mm}$. 
Table 1. Leiolima iberica gen. et sp. nov. Leg lengths of male holotype (in bold type) and average leg lengths of males $(n=4)$ and females (in parentheses, $n=4)$.

\begin{tabular}{cccccccc}
\hline & $\mathbf{t r}$ & $\mathbf{f e}$ & $\mathbf{p a}$ & $\mathbf{t i}$ & $\mathbf{m t}$ & $\mathbf{t a}$ & Total \\
\hline \multirow{2}{*}{ I } & $\mathbf{0 . 3 7}$ & $\mathbf{2 . 9 8}$ & $\mathbf{0 . 8 0}$ & $\mathbf{2 . 1 9}$ & $\mathbf{2 . 4 0}$ & $\mathbf{5 . 6 7}$ & $\mathbf{1 4 . 4 1}$ \\
& $0.4(0.4)$ & $3.3(2.9)$ & $1.0(0.9)$ & $2.6(2.3)$ & $2.8(2.3)$ & $6.8(5.1)$ & $16.5(13.5)$ \\
& $\mathbf{0 . 3 6}$ & $\mathbf{5 . 0 0}$ & $\mathbf{1 . 0 3}$ & $\mathbf{4 . 3 7}$ & $\mathbf{4 . 4 2}$ & $\mathbf{1 1 . 9 2}$ & $\mathbf{2 7 . 1 0}$ \\
II & $0.4(0.4)$ & $5.7(4.9)$ & $1.2(1.2)$ & $5.0(4.5)$ & $5.0(4.3)$ & $13.5(11.2)$ & $30.4(26.1)$ \\
& $\mathbf{0 . 3 7}$ & $\mathbf{3 . 1 7}$ & $\mathbf{0 . 8 8}$ & $\mathbf{2 . 2 8}$ & $\mathbf{2 . 7 8}$ & $\mathbf{5 . 9 1}$ & $\mathbf{1 5 . 3 9}$ \\
III & $0.4(0.4)$ & $3.6(3.1)$ & $1.0(0.9)$ & $2.6(2.3)$ & $3.2(2.7)$ & $6.6(5.2)$ & $17.0(14.2)$ \\
& $\mathbf{0 . 4 1}$ & $\mathbf{5 . 2 7}$ & $\mathbf{1 . 0 5}$ & $\mathbf{3 . 4 4}$ & $\mathbf{4 . 6 8}$ & $\mathbf{7 . 7 7}$ & $\mathbf{2 2 . 6 2}$ \\
IV & $0.4(0.4)$ & $5.7(4.9)$ & $1.2(1.1)$ & $3.9(3.4)$ & $5.2(4.5)$ & $8.7(6.8)$ & $24.7(20.7)$ \\
\hline
\end{tabular}

ZUPV $1419 \bullet 1$ วं; Quintanilha; $41.720^{\circ} \mathrm{N}, 6.589^{\circ} \mathrm{W} ; 600 \mathrm{~m}$ a.s.1.; 11 Nov. 1988; K. Altonaga and R. Gorrotxategi leg.; ruderal; ZUPV 1532 - 1 đo; Vimioso; $41.593^{\circ} \mathrm{N}, 6.558^{\circ} \mathrm{W} ; 500 \mathrm{~m}$ a.s.1.; 11 Nov. 1988; K. Altonaga and R. Gorrotxategi leg.; ruderal; ZUPV 1497. - Guarda Distr. • 1 `; Seia, Cabeça; $40.324^{\circ} \mathrm{N}, 7.746^{\circ} \mathrm{W} ; 550 \mathrm{~m}$ a.s.1.; Dec. 1998; Grosso-Silva leg.; ZUPV $4104 \cdot 2$ ô ${ }^{\wedge}, 2$ 우; same collection data as for preceding; Jan. 1999; Grosso-Silva leg.; ZUPV 4108.

\section{Remarks}

Paratype specimens (male and female) from Freixo de Espada (Bragança, Portugal; samples ZUPV 3324, 3330, 5000 and 5001) have been deposited at the SMF: 0 (ZUPV 3324), $q$ (ZUPV 5000);

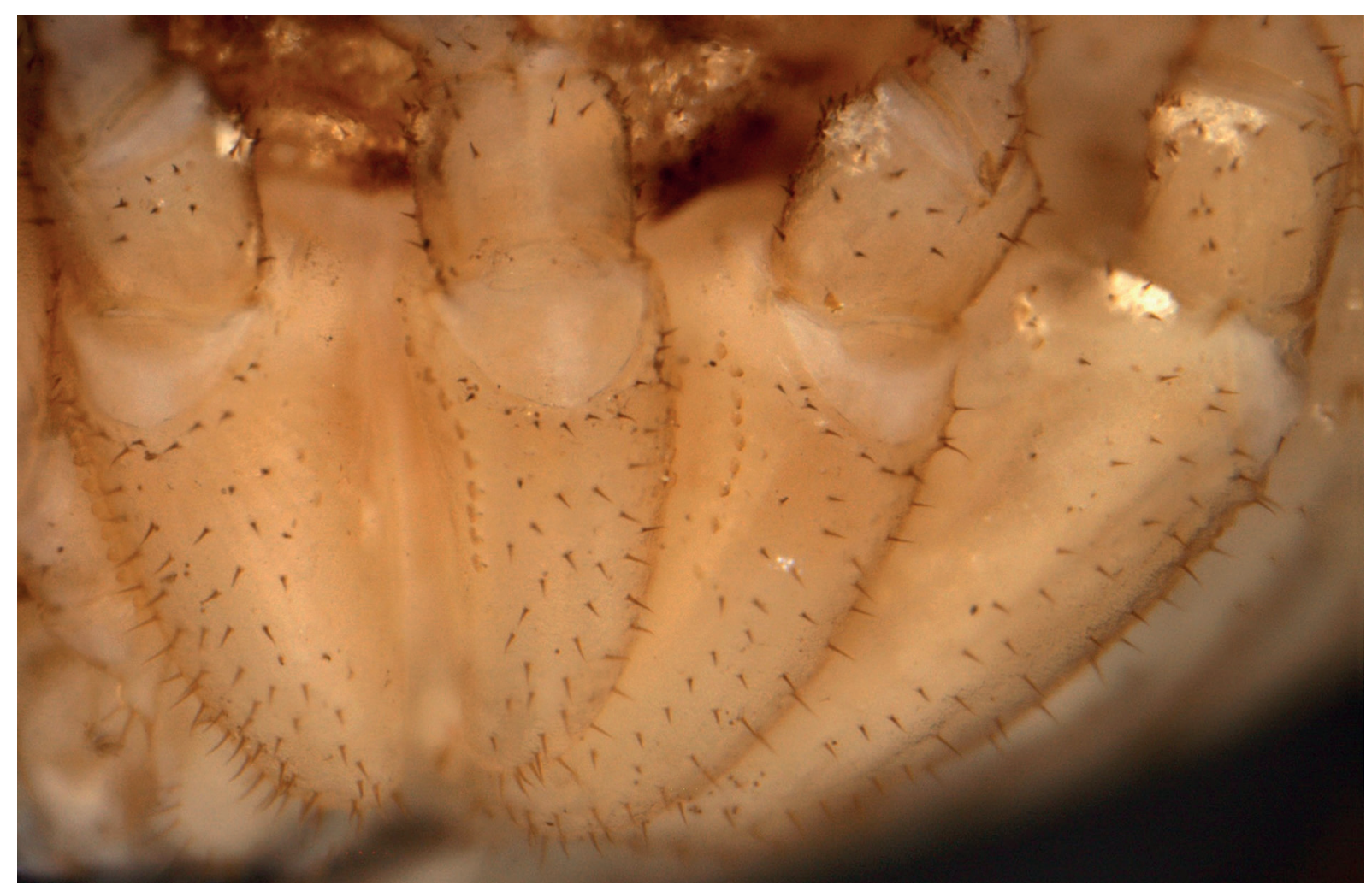

Fig. 2. Leiolima iberica gen. et sp. nov. Lateral view of the male holotype (MNCN 20.02/17372) (left is front side), showing coxae I to IV with coxal denticle rows. 
Prieto C.E. \& Wijnhoven H., Leiolima (Opiliones, Sclerosomatidae), a new genus from Iberia

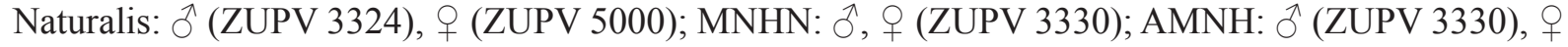
(ZUPV 5001).

\section{Description}

Male (holotype, Fig. 1)

Body length 3.15, prosoma width 1.85, and BLI index 1.61. Leg lengths (Table 1).

Prosoma. Anterior margin slightly concave on both sides and midsection protruding (Fig. 1). Cheliceral apodemes appear as two narrow stripes. Supracheliceral lamellae with two cylindrical protuberances, each having three or four apical granules (Fig. 4C). Ozopores close to anterolateral margin, rounded and minute (0.04-0.05 diameter).

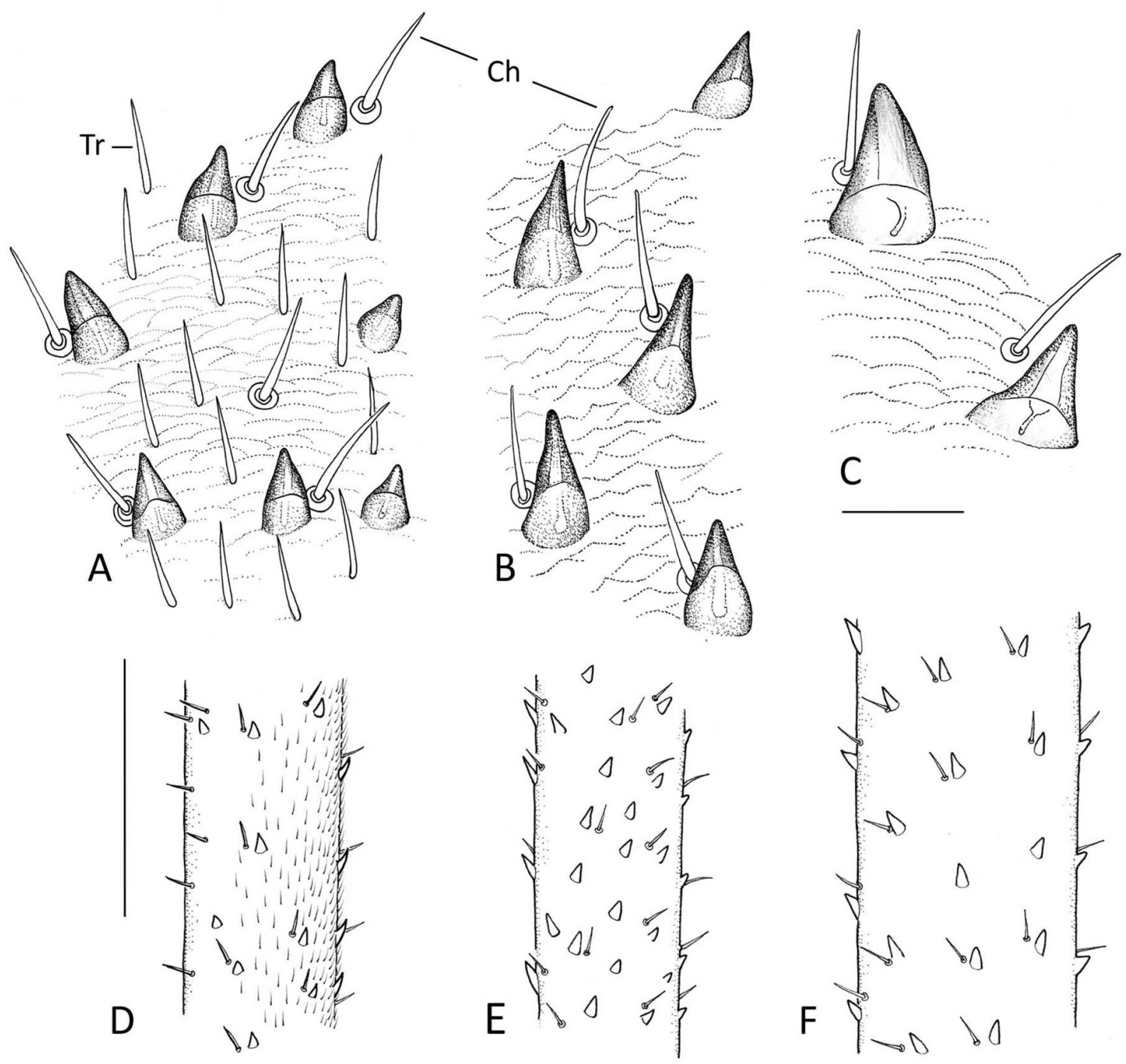

Fig. 3. Male femur I of three European species of Leiobuninae. A, D. Leiolima iberica gen. et sp. nov. (ZUPV 3330 at CHW). B, E. Nelima doriae (Canestrini, 1871) (from the Netherlands). C, F. Leiobunum rotundum (Latreille, 1798). A-C. Dorsal view. D-F. Lateral view (dorsal side on the right). Ch $=$ sensillum chaeticum; $\mathrm{Tr}=$ trichome (trichomes in $\mathrm{D}$ drawn smaller). Scale bars: A-C $=0.05 \mathrm{~mm}$; D-F $=0.5 \mathrm{~mm}$. 
Table 2. Leiolima iberica gen. et sp. nov., number of tubercles on lateral margins of leg coxae $(\mathrm{n}=11$ males, 7 females). Averages on the right are from right coxae, and averages on the left come from the combined results on both sides. Catalogue numbers refer to the ZUPV collection.

\begin{tabular}{|c|c|c|c|c|c|c|c|c|c|c|c|c|c|c|c|c|}
\hline \multirow{2}{*}{\begin{tabular}{|l|} 
Leg \\
MALES
\end{tabular}} & \multicolumn{2}{|c|}{ I } & \multicolumn{2}{|c|}{ II } & \multicolumn{2}{|c|}{ III } & \multicolumn{2}{|c|}{ IV } & \multicolumn{2}{|c|}{ I (r) } & \multicolumn{2}{|c|}{ II (r) } & \multicolumn{2}{|c|}{ III (r) } & \multicolumn{2}{|c|}{ IV (r) } \\
\hline & $\mathbf{A}$ & $\mathbf{P}$ & $\mathbf{A}$ & $\mathbf{P}$ & A & $\mathbf{P}$ & $\mathbf{A}$ & $\mathbf{P}$ & A & $\mathbf{P}$ & A & $\mathbf{P}$ & $\mathbf{A}$ & $\mathbf{P}$ & $\mathbf{A}$ & $\mathbf{P}$ \\
\hline 3279 & 12 & 8 & 8 & 2 & 8 & 1 & 3 & 8 & 12 & 5 & 12 & 6 & 7 & 3 & 6 & 7 \\
\hline 3324 & 8 & 4 & 9 & 4 & 9 & 0 & 0 & 7 & 10 & 4 & 7 & 4 & 7 & 0 & 0 & 8 \\
\hline 3330 & 13 & 0 & 10 & 3 & 9 & 0 & 3 & 7 & 12 & 0 & 12 & 1 & 9 & 0 & 3 & 7 \\
\hline 3330 & 12 & 0 & 10 & 7 & 8 & 0 & 3 & 6 & 11 & 2 & 9 & 6 & 9 & 0 & 8 & 6 \\
\hline 3333 & 12 & 2 & 6 & 6 & 8 & 0 & 6 & 5 & 11 & 2 & 8 & 2 & 8 & 0 & 2 & 7 \\
\hline 3809 & 9 & 2 & 9 & 4 & 9 & 0 & 4 & 7 & 12 & 2 & 10 & 4 & 8 & 0 & 2 & 6 \\
\hline 3821 & 11 & 4 & 12 & 7 & 8 & 0 & 3 & 7 & 9 & 2 & 10 & 6 & 11 & 0 & 4 & 6 \\
\hline 4108 & 14 & 7 & 10 & 9 & 12 & 0 & 2 & 9 & 16 & 4 & 11 & - & 11 & 1 & 3 & 10 \\
\hline 4108 & 13 & 8 & 10 & 9 & 8 & 0 & 3 & 10 & 14 & 9 & 11 & 9 & 10 & 0 & 3 & 9 \\
\hline 4108 & 12 & 10 & 12 & 9 & 10 & 0 & 4 & 8 & 12 & 5 & 11 & 7 & 12 & 0 & 4 & 7 \\
\hline 4261 & 7 & 0 & 7 & 0 & 7 & 0 & 2 & 4 & 9 & 0 & 9 & 0 & 7 & 0 & 1 & 7 \\
\hline average & 11.2 & 4.1 & 9.4 & 5.5 & 8.7 & 0.1 & 3 & 7.1 & 11.6 & 3.2 & 10 & 4.5 & 9 & 0.4 & 3.3 & 7.3 \\
\hline \multicolumn{17}{|c|}{ FEMALES } \\
\hline 1446 & 14 & 8 & 11 & 6 & 9 & 0 & 7 & 11 & 12 & 8 & 10 & 8 & 8 & 0 & 6 & 11 \\
\hline 3330 & 10 & 1 & 8 & 4 & 8 & 0 & 3 & 7 & 8 & 0 & 8 & 2 & 7 & 0 & 3 & 8 \\
\hline 3333 & 12 & 0 & 10 & 4 & 6 & 0 & 3 & 7 & 11 & 0 & 11 & 2 & 10 & 0 & 2 & 7 \\
\hline 3333 & 11 & 2 & 10 & 2 & 8 & 0 & 1 & 7 & 11 & 0 & 11 & 4 & 8 & 0 & 1 & 6 \\
\hline 3809 & 9 & 2 & 9 & 4 & 9 & 0 & 4 & 7 & 12 & 2 & 10 & 4 & 8 & 0 & 2 & 6 \\
\hline 4108 & 13 & 2 & 10 & 7 & 7 & 0 & 0 & 8 & 13 & 2 & 11 & 7 & 9 & 0 & 2 & 11 \\
\hline 4108 & 12 & 7 & 10 & 8 & 9 & 0 & 2 & 11 & 13 & 8 & 11 & 10 & 8 & 0 & 0 & 11 \\
\hline average & 11.6 & 3.1 & 9.7 & 5 & 8 & 0 & 2.9 & 8.3 & 11.4 & 2.9 & 10.3 & 5.3 & 8.3 & 0 & 2.3 & 8.6 \\
\hline
\end{tabular}

Dorsum. Dorsal integument with a microtuberculate-microgranulate morphology, consist of distinct obtuse to acute granules, approximately separated by their width. Granules towards sides more prominent.

Coloration of DORSum. Dorsum dark reddish-brown with black granules and numerous scattered yellowish to silvery spots, especially prominent near sides of prosoma (Fig. 1). Saddle as faint pattern of two paramedian longitudinal bands of diffuse and blackish segmental patches. Muscle insertion plaques dark brown. Area in front of ocularium dark brown. Prosoma bordered with black.

OCULARIUM. Shallow, basally constricted canaliculate, covered with large granules and dorsally armed with two rows of pointed black denticles, with a few sensilla chaetica (Fig. 4D). Eyes (diameter 0.15) on a black ocularium ( 0.32 long, 0.35 wide), base reddish-brown. Ocularium located about its length from anterior margin of prosoma.

VENTER AND COXAE. Coxae smooth, pale yellowish, armed with numerous black sensilla chaetica, distal pro- and posteriolateral sides with short rows of tubercles (Fig. 2). Posteriolateral side of coxa III without or rarely with sparse tubercles (Table 2). The resulting coxal tubercle formula can be expressed as Ap Ap A- aP [A, P, anterior, posterior row (lowercase for weakly developed ones) from $1^{\text {st }}$ to $4^{\text {th }}$ leg 
coxae]. Largest individual coxal tubercles $25-30 \mu \mathrm{m}$ in height, separated from each other by $20-30 \mu \mathrm{m}$, with upper flange wider than basal width, bevelled towards their coxa and trilobed, being higher than central lobe. Ventral side pale yellowish. Epistome conical and 0.3 long. Genital operculum with sensilla chaetica, laterally with few obtuse denticles (Fig. 4A); internal side of anterior end of genital operculum without sclerotized lobes or any other cuticular structure.

Chelicerae. Smooth, pale yellowish, dorsal area of first segment darkened and provided with 'sensilla chaetica' (Fig. 4B).

Pedipalps. Pale yellowish, distal areas of femur darkened, as well as patella and tibia. Femur covered with large black sensilla chaetica, medially with black-tipped blunt denticles (Fig. 5); a single spine occurs dorsodistally. Pedipalpal tarsus almost straight, only very slightly curved inward, claw pectinate (Fig. 5B), without ventral rows of denticles. Pedipalpal patella, tibia and tarsus covered with trichomes (non-sensorial, not socketed "setae"). Dorsal regions of patella and tibia with fields of robust, transparent trichomes (Fig. 5D).

LEGs. Medium long and slender (Table 1; BLI = 1.62 in holotype), orange-brown, mottled with small silvery spots, especially on dorsal sides of patella and tibia. Trochanters with bright patches on anterior
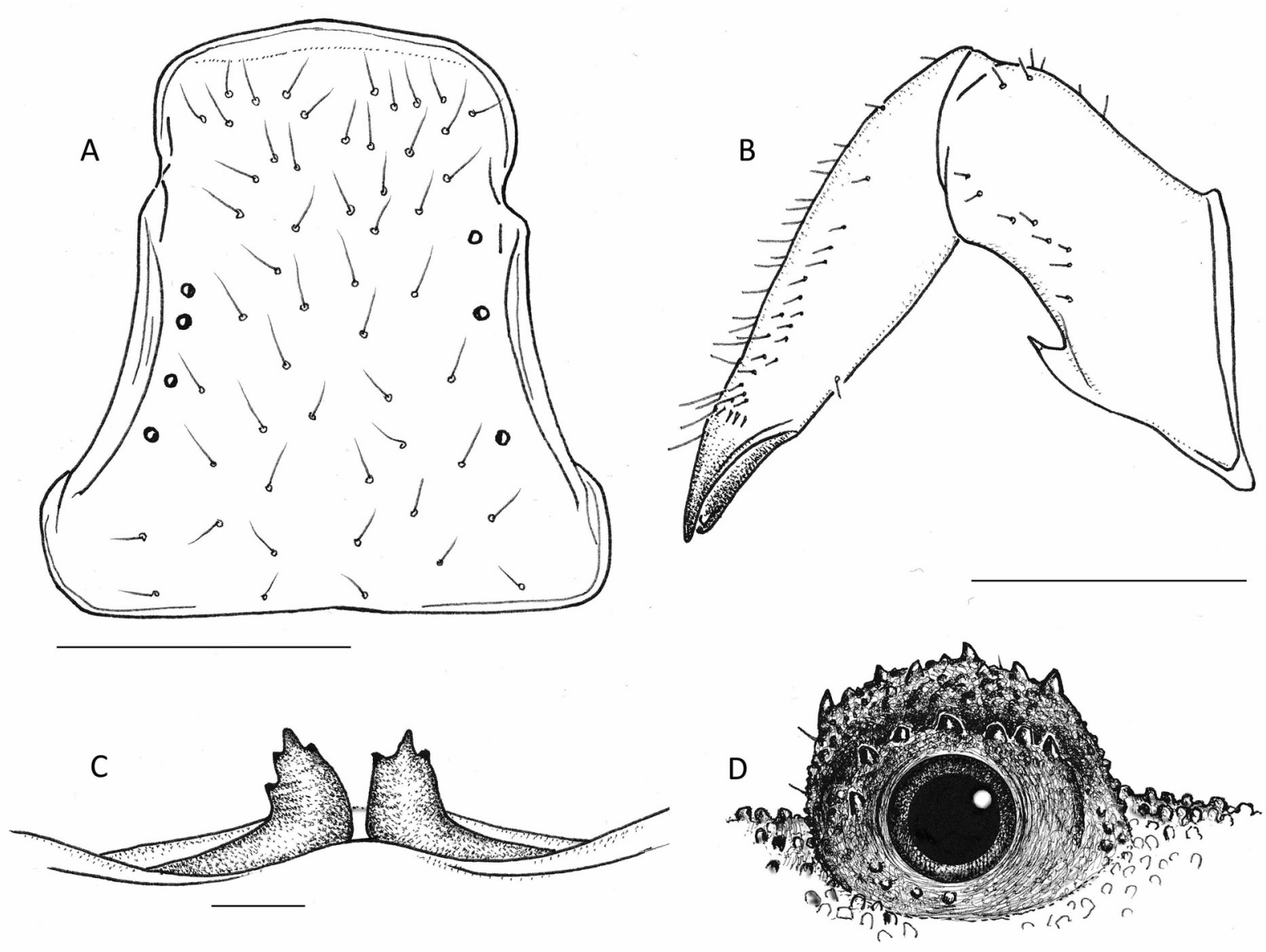

Fig. 4. Leiolima iberica gen. et sp. nov. (male) (holotype, MNCN 20.02/17372). A. Genital operculum. B. Right chelicera (median view). C. Supracheliceral lamellae (dorsal view). D. Ocularium (lateral view; front side on the right). Scale bars: $\mathrm{A}-\mathrm{B}=0.5 \mathrm{~mm}$; $\mathrm{C}-\mathrm{D}=0.1 \mathrm{~mm}$. 
and posterior sides. Femur I conspicuously shorter (59.5\% in holotype) and more robust than femur II. Femora with irregular rows of small, black-tipped spines, each accompanied by a 'sensillum chaeticum'. Tibia II has 5-6 silvery bordered pseudoarticulations. Patellae with three pointed granules on dorsodistal margin. All femora, except ventrally, densely covered with trichomes (Fig. 3A, D), which also occur on patella, tibiae, metatarsi and tarsi of all legs.

PenIs. Truncus slightly and regularly narrowing towards top (Fig. 6). Alate portion well developed and elongated, consisting of two dorsal and two ventral membranes which are fused only in proximal onequarter section, thus forming two pockets that open to exterior distally as well as laterally. Ventral membranes attached at truncus/glans junction and have a characteristically curved distal margin. Dorsal membranes attached more proximally, extending on to ventral side, forming two wings that partly enclose ventral membranes. Distal margins of ventral membranes have an irregular 'worn-down' appearance (Fig. 6D). Glans and stylus with characteristic shape (Fig. 6F-G) and four sensilla chaetica located near tip. Measurements: penis length 1.83 , glans + stylus length 0.29 , truncus length from base to pockets 0.91 , penial muscle length 0.77 , basal truncus width 0.23 , width of alae 0.32 .

Female (Fig. 1)

Body length 5.58, prosoma width 2.17, opisthosoma width 3.29, BLI index 1.24.

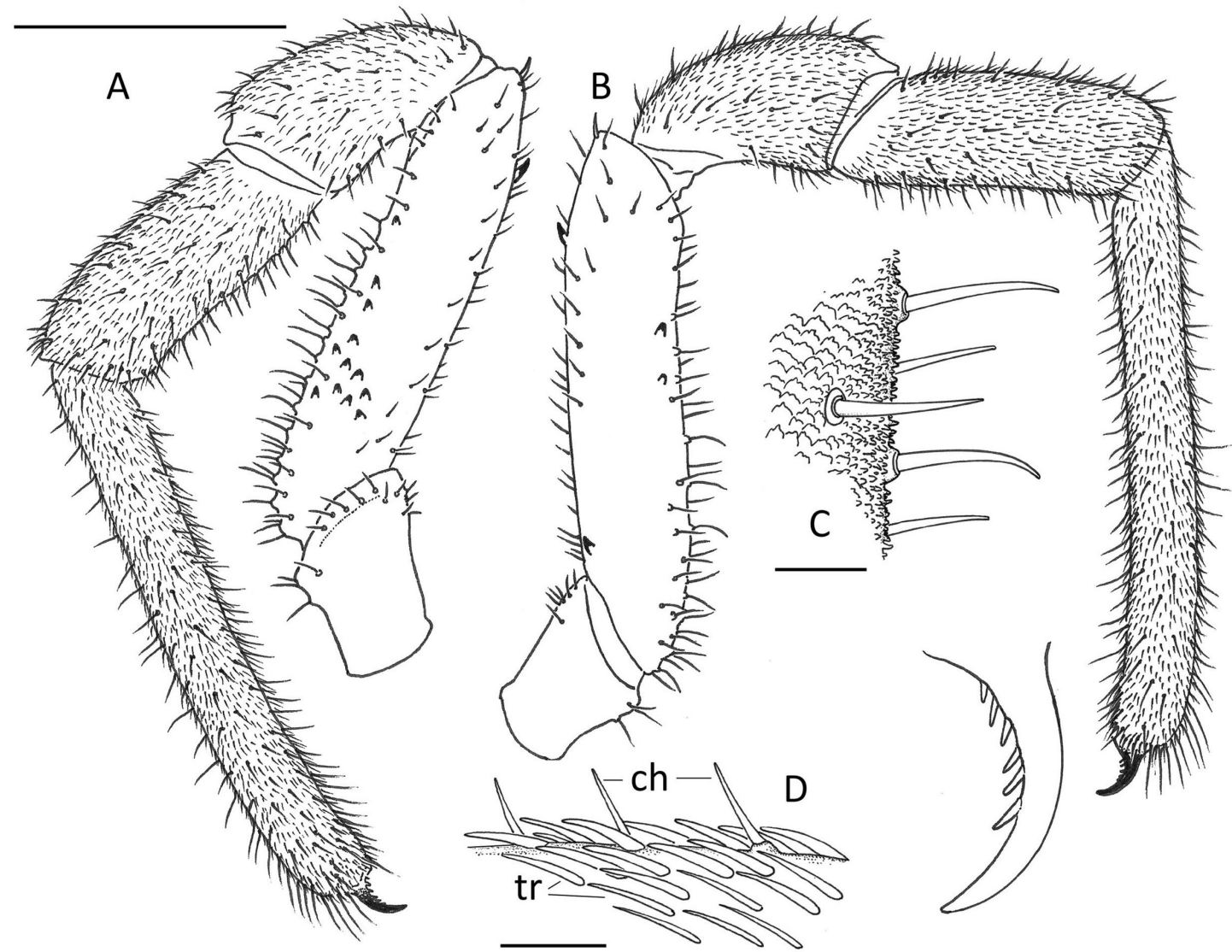

Fig. 5. Right male pedipalp of Leiolima iberica gen. et sp. nov. (holotype, MNCN 20.02/17372). A. Median view. B. Lateral view with detail of claw. C. Detail of ventral side of femur showing sensilla chaetica and imbricate microsculpture. D. Detail of dorsal side of patella showing robust trichomes (tr) and sensilla chaetica (ch). Scale bars: A-B $=0.5 \mathrm{~mm} ; \mathrm{C}-\mathrm{D}=0.05 \mathrm{~mm}$. 
LEGs. Long, with legs I, III and IV more robust than in male, leg II slender. Femur of leg I more than twice as wide as that of leg II (Table 1).

Seminal ReCEPTACles (Fig. 7). In fourth to fifth ovipositor segments.
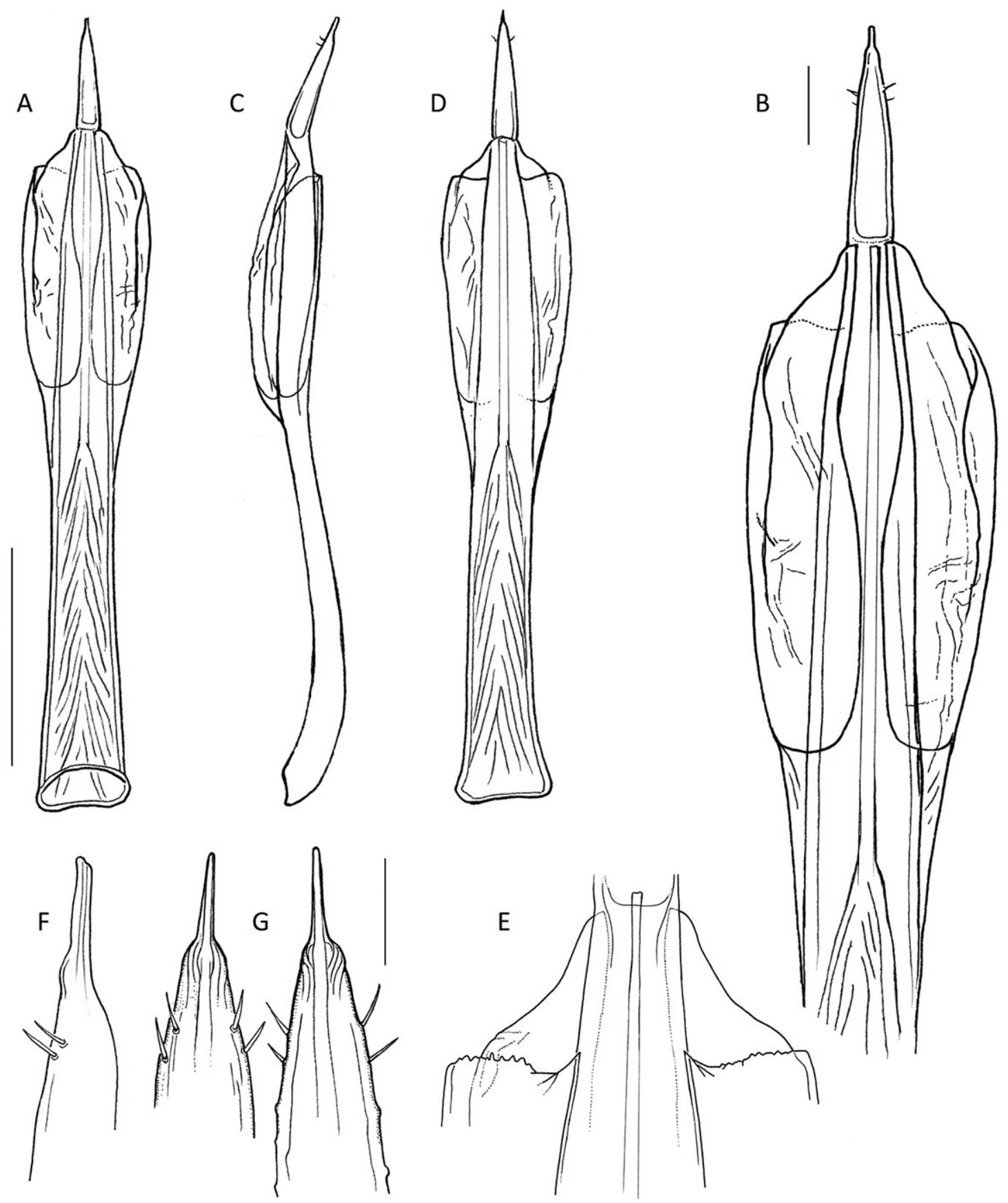

Fig. 6. Penis of Leiolima iberica gen. et sp. nov. A. Ventral view. B. Detail of distal part (ventral view). C. Lateral view. D. Dorsal view. E. Attachment sites of dorsal and ventral membranes (dorsal view). F. Stylus (lateral view, ventral side to left). G. Stylus of two males in ventral (left) and dorsal (right) view. A, G: paratypes, ZUPV 3330 at CHW; B-F: paratype, ZUPV 4261 at CHW. Scale bars: A, C-D = $0.5 \mathrm{~mm} ; \mathrm{B}=0.1 \mathrm{~mm} ; \mathrm{F}-\mathrm{G}=0.05 \mathrm{~mm}$. 


\section{Sexual dimorphism}

Leiolima iberica gen. et sp. nov. shows minor sexual dimorphism. Females present smaller silvery patches on the prosoma and the length of the first thoracic tergite is about twice that in males. Legs are $1 / 6$ shorter than in males, but female bodies are almost twice as long as male ones, with the opisthosoma greatly enlarged in egg-developing females.

\section{Distribution}

Leiolima iberica gen. et sp. nov. is an Iberian endemic restricted to the north-western corner of the Iberian Peninsula (Fig. 8). The known distribution extends along the mountainous areas ranging from the north-western part of Castilla y León (Spanish provinces of León and Zamora) and the eastern part of the old Tras-os-Montes e Alto Douro region (Portuguese district of Bragança) to the mountain range that separates the Duero/Douro basin from the Tajo/Tejo basin (Serra da Estrela in Portugal, and Sierra de Francia and Sierra de Gredos in Spain). Galicia, Asturias or Extremadura have no records, although it may exist in the border areas.
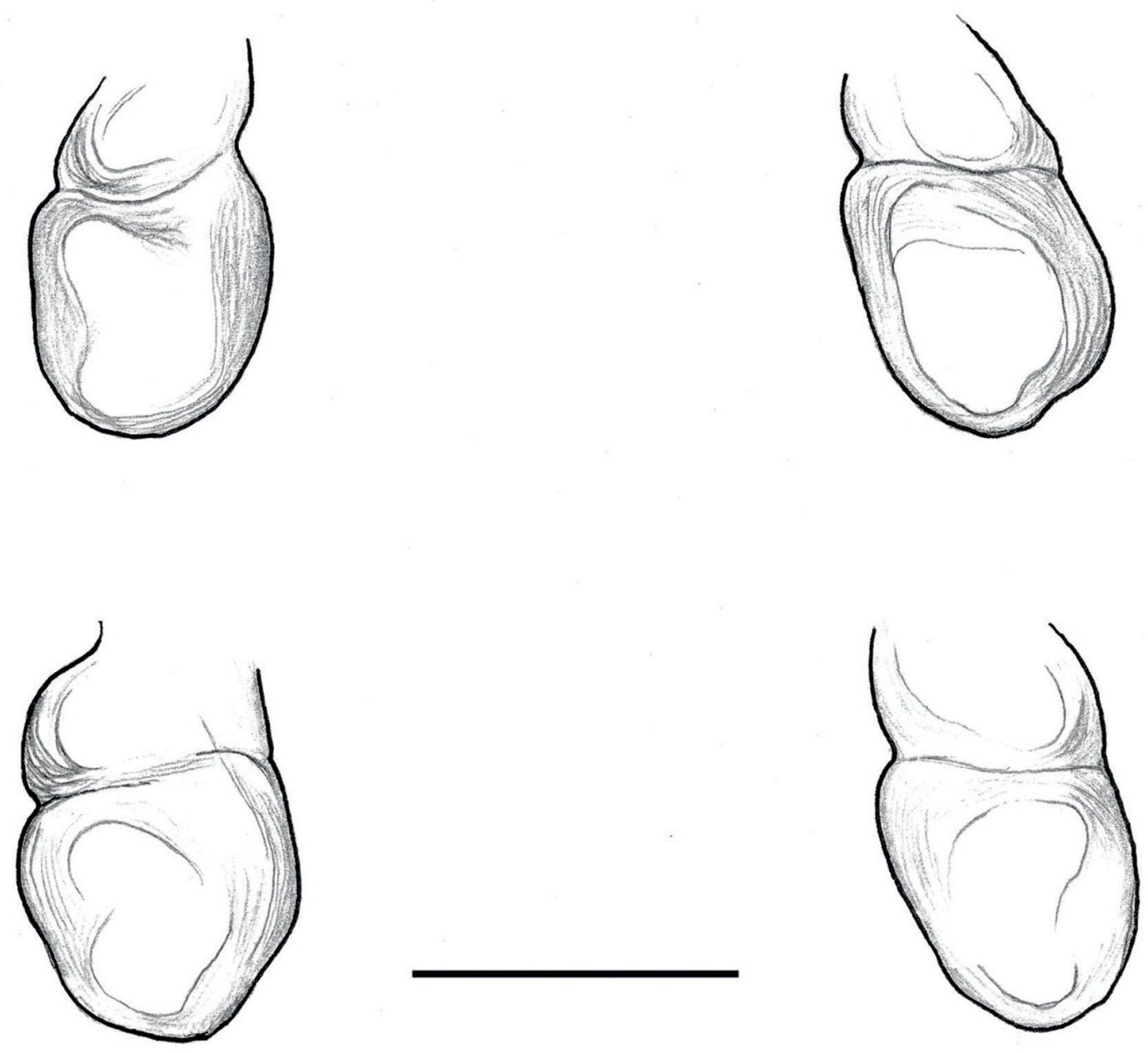

Fig. 7. Female Leiolima iberica gen. et sp. nov.; seminal receptacles, distance between left and right receptacles to scale. Paratypes: top: ZUPV 3333 at CHW, bottom ZUPV 4108 at CHW. Scale bar: $50 \mu \mathrm{m}$. 
It is possible to recognize a northern concentration and a southern block, separated by less than $100 \mathrm{~km}$. Although both are separated by the deep canyons of the Duero/Douro River bordering Spain and Portugal, here we assume a continuous distribution of the species. In the southern area, the only known locality of the Portuguese Serra da Estrela is $150 \mathrm{~km}$ west of the Sierra de Gata region of Spain. The similar orogeny and geography, as well as the absence of obvious physical barriers, make their presence in the comprised area probable. The eastern border of its known distribution area in Castilla y León is marked by the Órbigo River (a tributary of the Esla River), which separates the Montes de León from the vast plains of the Duero basin, which are mainly cultivated with cereals.

\section{Habitat}

Leiolima iberica gen. et sp. nov. is a species that lives in dry open biotopes, mainly pastures, grasslands and ruderal biotopes. It seems to fill the characteristic Nelima niches (ground and herb layer, sheltering under stones, wood and vegetation). The altitudinal range is $360-1350 \mathrm{~m}$ a.s.l. (average $782 \mathrm{~m}$ ), with two somewhat divergent localities: the Porrais site (360 m a.s.1.) is near the bottom of the Sabor River (a tributary of the Douro River), whereas the Peña de Francia site (1350 m a.s.l.) is near the mountain top of the Sierra de Francia. The average altitude of the 129 sampled localities from the concerned provinces or districts represented in the ZUPV collection is $975 \mathrm{~m}$, which on average is distinctly higher, suggesting that L. iberica gen. et sp. nov. is a 'lowland' species.

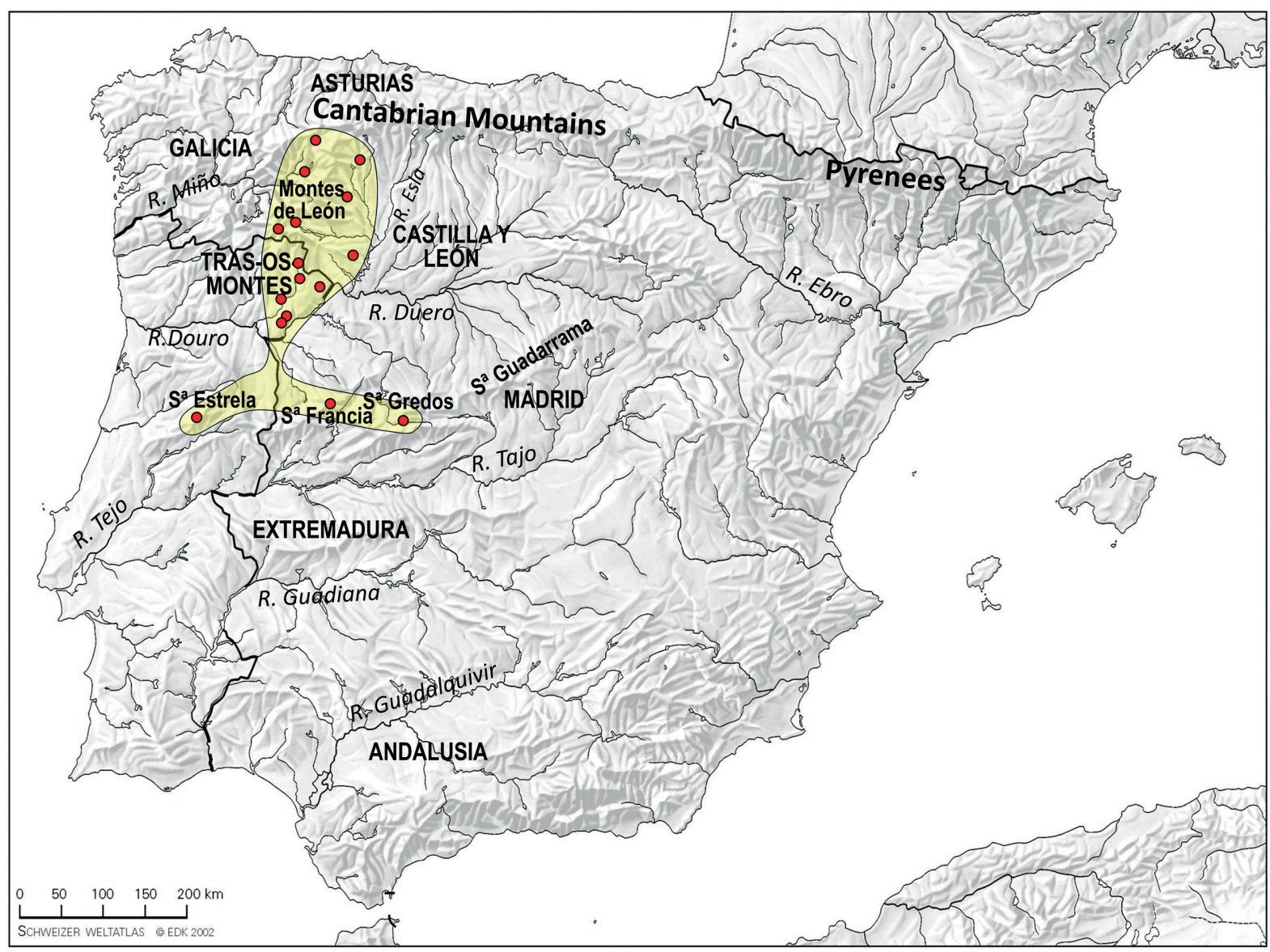

Fig. 8. Geographical distribution of Leiolima iberica gen. et sp. nov. on the Iberian Peninsula. Some names of autonomic or regional entities (in capitals, without borders), mountain ranges and larger rivers (in italics) are given. 


\section{Phenology}

Adults of Leiolima iberica gen. et sp. nov. have been obtained from September to February, mainly during malacological sampling trips. Because sampling outside of the appropriate season for land snails was infrequent, phenological information is biased. The collected specimens resulted in a sex ratio of 2.07, which is about two males per female. The bimonthly sex ratio figures ( 7 males / 3 females in Sep.Oct.; 11 / 0 in Nov.-Dec.; 11 / 11 in Jan.-Feb.) does not allow further conclusions about its life cycle, which is also obscured by the total absence of juvenile specimens in the samples.

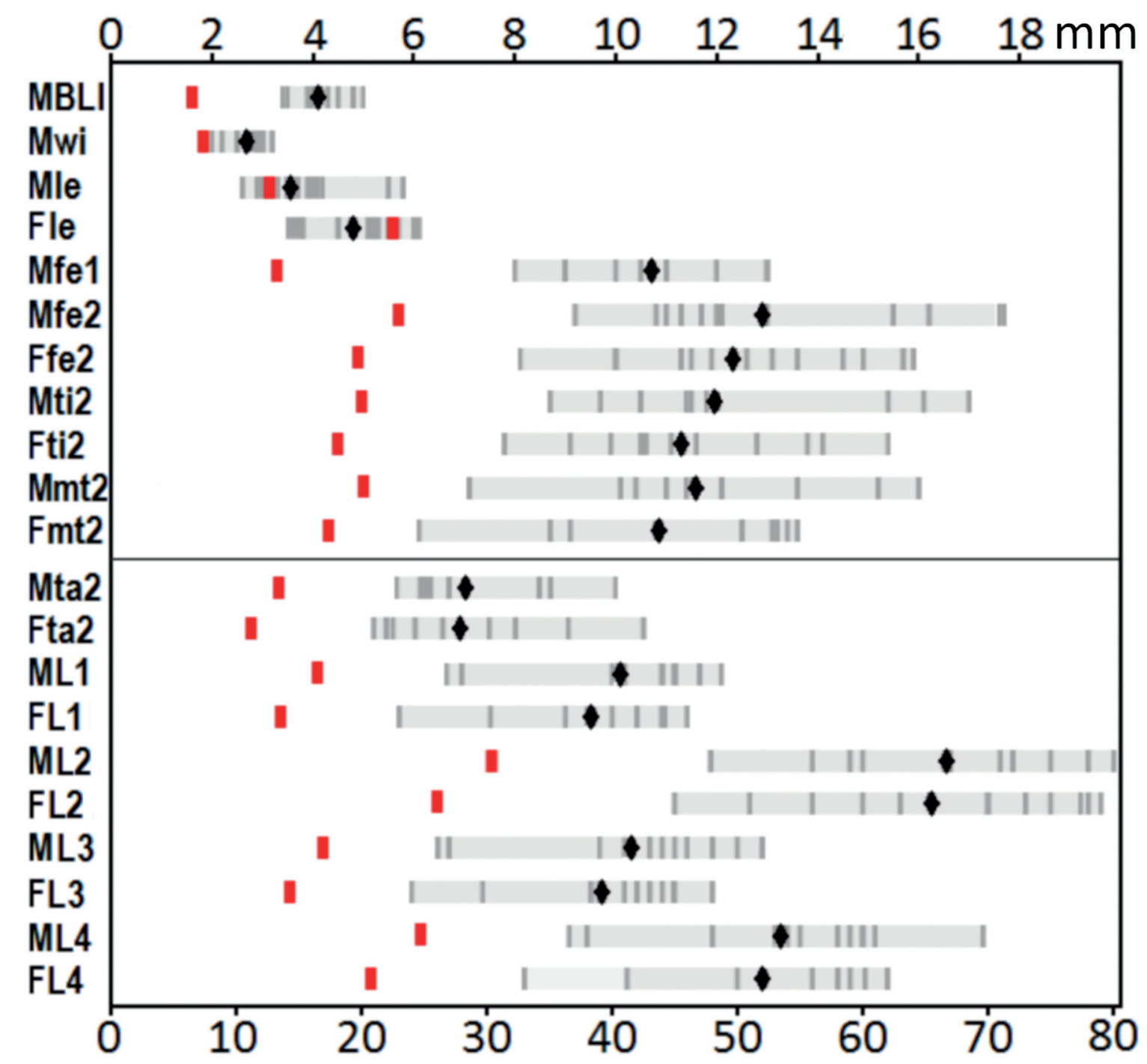

Fig. 9. Body size and leg length measurements (in mm apart from the MBLI ratio) of all European/ Mahgrebian species of Leiobunum C.L. Koch, 1839 (grey bars, diamonds on averages) and Leiolima iberica gen. et sp. nov. (red rectangles). Only the measured parameters for L. iberica gen. et sp. nov. are shown. Source of data: Caporiacco (1929), Karaman (1996), Komposch (1998), Martens (1978), Prieto \& Fernández (2007), Prieto \& Wijnhoven (2017) and Šilhavý (1965). 
Prieto C.E. \& Wijnhoven H., Leiolima (Opiliones, Sclerosomatidae), a new genus from Iberia

\section{Discussion}

Leiolima iberica gen. et sp. nov. represents a new Iberian species with some peculiar features. Evidently, the generic name itself is an expression of our reservations regarding the placement of this species within Leiobuninae. However, as mentioned earlier, it reflects the need for a general revision of the European Sclerosomatidae.

Therefore, due to the presence of coxal tubercle rows, the new species should be included in Leiobunum, as suggested by Prieto (2008), where this taxon is mentioned for the first time as an undescribed species. As mentioned earlier, Roewer (1923) based the separation between Leiobunum and Nelima on the single criterion of the presence (Leiobunum) or absence (Nelima) of rows of tubercles on both, anterior and posterior, margins of the leg coxae. The genus Cosmobunus was not considered a related genus at that time because Roewer $(1923,1957)$ included it in the North American subfamily Leptobuninae, which was dismantled by Cokendolpher (1985), transferring Cosmobunus to the subfamily Leiobuninae. Martens (1978) retained this system due to the absence of alternatives.

The fuzzy taxonomy of the family Sclerosomatidae has been revealed by a molecular analysis of Hedin et al. (2012). The placement of the sclerosomatid Gyas titanus (Gyinae) in the Phalangiidae ingroup, highly supported by combined Bayesian analysis and recently confirmed by Fernández et al. (2017) through transcriptomic analysis, is an outstanding result that agrees with the absence of coxal tubercle rows, a key feature of the family Phalangiidae (Tsurusaki 2007). Besides Gyas titanus, Hedin's phylograms show a limited representation of seven European sclerosomatids; that is, three Leiobunum and three Nelima species plus Astrobunus grallator (although Cosmobunus is missing). Interestingly, in the 28S Bayesian phylogram, these seven taxa were recovered in basal positions within a clade that has several New World gagrellines but not a single New World Leiobuninae. In the combined Bayesian analysis, all the extra-European leiobunines and Japanese gagrellines constitute a highly supported monophyletic clade, whereas the two European taxa (Nelima doriae and Astrobunus) constitute the sister clade of the New World gagrellines (Trachyrhinus Weed, 1892 and Krusa Goodnight \& Goodnight,

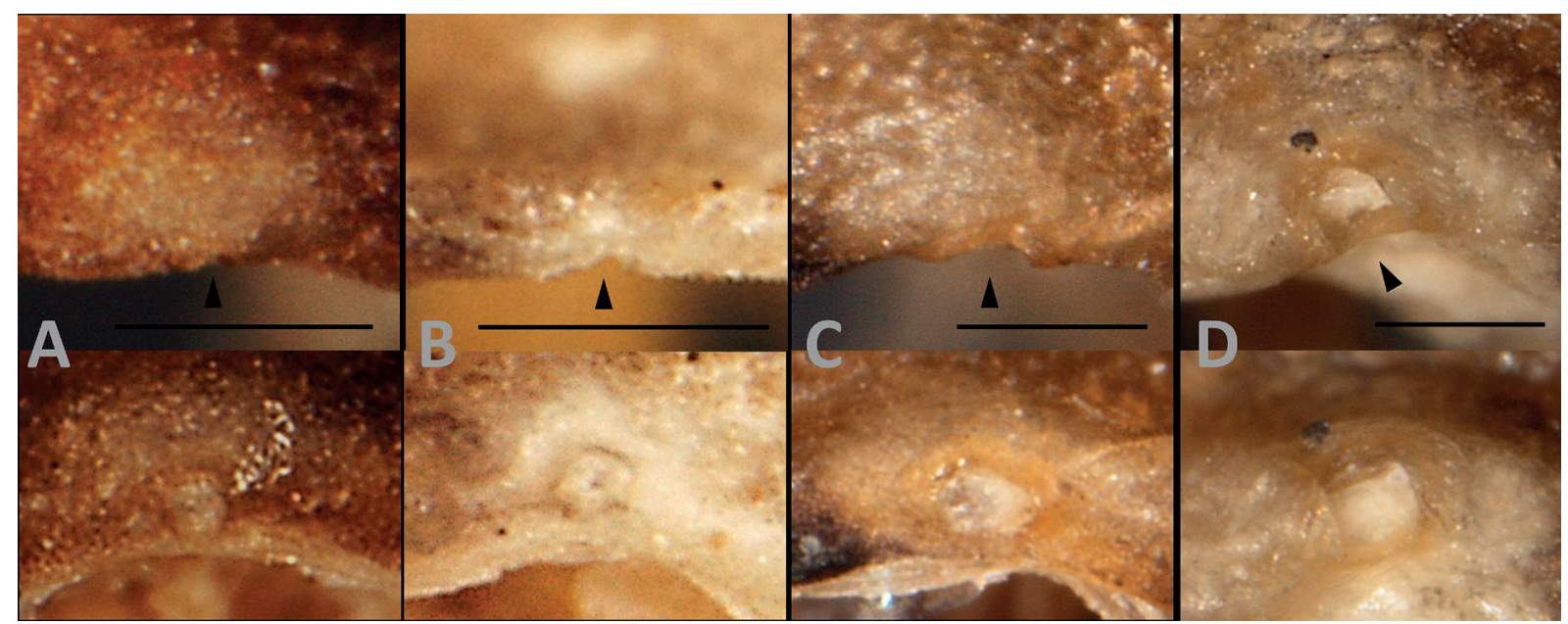

Fig. 10. Orifices of repugnatorial glands of the type species of European genera of Leiobuninae in dorsal (upper) and lateral (lower) views. A. Leiolima iberica gen. et sp. nov. (male, ZUPV 4104). B. Nelima silvatica (Simon, 1879) (male, ZUPV 1316: Castarnés, Huesca, Spain). C. Leiobunum rotundum (Latreille, 1798) (male, ZUPV 5065: Oña, Burgos, Spain). D. Cosmobunus granarius Lucas, 1846 (male, ZUPV 1932: Hornos, Jaén, Spain). Coxae I were removed to improve vision and images have been resized in proportion to their respective prosomal width $(\mathrm{A}=111 \% ; \mathrm{B}=125 \% ; \mathrm{C}=82 \%$; $=$ $73 \%$ ). Arrowheads in upper views point to the orifices. Scale bars: $0.1 \mathrm{~mm}$. 
1957). Therefore, if the European and American leiobunine taxa belong to two unrelated groups, each species group of the polyphyletic 'Leiobunum' and 'Nelima' from each biogeographical region would deserve a generic status. Given that the type species of Leiobunum and Nelima are European taxa, a taxonomical revision would require a complete reorganization of the Japanese and North American taxa. For example, the so-called "US Leiobunines" clade in Hedin et al. (2012: fig. 2) includes 13 'Leiobunum'spp., and the two Eumesosoma spp. and 'Hadrobunus sp.' would have to be grouped under Hadrobunus Banks, 1900 or, more likely, the resurrection of Forbesium Weed, 1890, the older name for New World leiobunums, with priority over Eumesosoma Cokendolpher, 1980, if the respective type species (not analysed) also belong to this clade. Alternatively, the genus Krusa, which was shown to be polyphyletic, with two species (one being the type) related to Trachyrhinus and two others in a clade together with a 'Leiobunum' and a 'Nelima' nov. sp. 1, would require a new generic name. In this sense, Gaona-Escamilla et al. (2016), restraining the use of Krusa to the former group, consider that the presence of a smooth ocularium and a lobed penis justifies that 'Krusa' flava and 'Krusa' metallica should be placed in another unnamed genus.

As Hedin et al. (2012) also pointed out, some characters are prone to homoplasy in Leiobuninae due to heterochronic parallelism processes, e.g., the presence of coxal tubercle rows is a plesiomorphic feature among sclerosomatids, but the absence of these tubercles, diagnostic for Nelima, is a characteristic trait also for nymphal stages of Leiobunum (Hedin et al. 2012) and Cosmobunus (personal observation), a feature frequently observed but never reported in the literature. The existence of many endemic species of 'Nelima' in each region of its Holarctic range (North America, East Asia, Mediterranean Region) suggests multiple independent cases of paedomorphosis on different continents, which is evidenced by the existence (see phylograms in Hedin et al. 2012) of clusters of species of 'Nelima' nested in different Leiobunum clades from the United States and Japan. However, accepting this hypothesis of repeated pedomorphy does not imply that every species of Nelima arose by heterochronic processes, so plausibly, different species of 'Nelima' of each regional cluster evolved through other speciation processes, i.e., vicariance, from the ancestral pedomorphic species.

All of this reveals a taxonomical maze due to the enormous diversity of the family Sclerosomatidae, more than 1300 species, for which Hedin et al. (2012) propose a strategy of "sequence everything", beginning with a large sample (they suggest starting with about 500 species) to discover natural groups before a post hoc search for morphological synapomorphies. This would require paralyzing taxonomic research based on morphological reasons until fresh samples were obtained from the largely unknown East Asian diversity, including the type species of all genera. Not against that approach, but complementary, may be the creation of new genera based on new species if they do not fit into current genera. They, like any other taxa of any hierarchical level, are hypotheses that will be confirmed or refuted by future research, and their creation demands that the hypothesis should be contrasted in future comprehensive analyses. Shultz (2018) expresses a different point of view when describing a new North American species of Leiobunum, by recognizing the difficulty of its systematic placement because of the artificial definition and composition of genera of Roewerian, even considering its inclusion in other genera by the absence of coxal tubercles or the reduced pectination of the tarsal claw. Although its final plea for a broad-scale morphological and molecular revision of sclerosomatid harvestmen is shared, the situation is different in the western Palearctic region.

The situation of western Palearctic leiobunines seems less complex for three reasons. First, they include the type species of Leiobunum, Nelima and Cosmobunus. The latter became monotypic when Cokendolpher (1985) deprived it of the spurious American C. americanus Roewer, 1957; moreover, the Near Eastern genus Microliobunum Roewer, 1912 and the Persian Goasheer Snegovaya et al., 2018, rather distinctive by their very short legs (Roewer 1952; Snegovaya et al. 2018; Kurt 2018), remain valid taxa. Secondly, nearly all European leiobunines are well-known taxa that have recently 
Prieto C.E. \& Wijnhoven H., Leiolima (Opiliones, Sclerosomatidae), a new genus from Iberia

been described or revised (Martens 1978; Karaman 1996; Komposch 1998; Prieto \& Fernández 2007; Martens \& Schönhofer 2016; Wijnhoven \& Prieto 2017) and noteworthy faunistic novelties are conspicuous, whereas the Central American fauna is poorly known and many of the already named species are insufficiently described (Gaona-Escamilla et al. 2016). Thirdly, the European/Mahgrebian leiobunines show a greater penial uniformity; up to today it has not been possible to define clear groups of species in Leiobunum, whereas the American or Japanese faunas include such species groups (Suzuki 1976; Burns et al. 2012) which could rightly be recognized as separate genera.

Restraining the discussion to European taxa, we have based the placement of the new species in its own genus on two character sets, leg length and trichome cover on proximal podomeres. The relative length of legs with respect to the body, expressed as BLI index, is often used to diagnose genera. Sclerosomatines are ground-dwelling harvestmen with short legs and a heavier dorsal sclerotization with paired segmental protuberances on the scutum, a robust prosomal armature of spines or horns and trochanter spurs, whereas leiobunines are scansorial or rupicolous, without paired scutal protuberances or prosomal armature or trochanter spurs (Martens 1978; Hedin et al. 2012). These features place the new species herein described among the leiobunines, whereas the presence of pectination on the palpal claw precludes its belonging to Cosmobunus, and the presence of pro- and retrolateral rows of coxal tubercles would force its inclusion in Leiobunum, as has been said before. However, the new species show strikingly short legs, which is unlike any European Leiobunum (Fig. 9). While the body size of L. iberica gen. et sp. nov. lies in the size span of Leiobunum, with relatively large females (larger than the average size of females of Leiobunum), both the BLI index and leg measurements show that L. iberica gen. et sp. nov. is clearly situated outside the morphological space of the European (species of the) genus Leiobunum. Within this minor overall length, it is particularly prominent that the first leg of L. iberica gen. et sp. nov. is shorter than half the length of the first leg in the most short-legged Leiobunum.

The presence of a trichome cover on all the proximal leg podomeres, in addition to the normal ornamentation of denticles and 'sensilla chaetica', recorded as just setae or socketed setae in earlier literature (Willemart et al. 2009), according to our knowledge, is a unique feature among the WesternPalaearctic Leiobuninae (Wijnhoven 2013). In the three European genera of Leiobuninae known to date, trichomes occur only on the tibiae, metatarsi and tarsi of legs, lacking on femora and patellae. We checked this character for the following species: Nelima doriae (Fig. 3B, E), N. gothica Lohmander, 1945, N. sempronii Szalay, 1951, Leiobunum argentipalpe Prieto \& Fernández, 2007, L. blackwallii Meade, 1861, L. levantinum Prieto \& Fernández, 2007, L. rotundum (Fig. 3C, F), L. sp. (sensu Wijnhoven et al. 2007) and Cosmobunus granarius Lucas, 1846. However, in both juveniles and adults of Gyas titanus, the presence of trichomes on the femur and patella was confirmed (unpublished data). Also, the trichomes on the pedipalpal patella in addition to its normal occurrence on the tibia and tarsus, by our knowledge, is a peculiar unique feature within Leiobuninae. Although the taxonomic significance is unknown, another discrepant character with respect to Leiobunum, or at least its type species, is the size of the ozopores. They are circular and minute in L. iberica gen. et sp. nov. and $N$. silvatica $(0.05 \mathrm{~mm})$; larger and ovate in Leiobunum rotundum $(0.12 \times 0.6 \mathrm{~mm})$; and in Cosmobunus granarius, ozopores $(0.1$ $\times 0.11 \mathrm{~mm}$ ) appear as indentations of a carapace flange above coxa I (personal observations).

Leiolima iberica gen. et sp. nov. really seems to deserve an assignment between Nelima and Leiobunum. The dorsal microsculpture consisting of isolated granules is a character for many species of Nelima, such as $N$. doriae and $N$. sempronii. In Leiolima iberica gen. et sp. nov. these granules are rather large, whereas in species of Nelima these are generally less conspicuous. The European species of Leiobunum usually have a rugose dorsal microstructure with pointed microdenticles. Also, the ocularium is Nelimalike, with two rows of teeth, whereas the ocularium is smooth in most species of Leiobunum. The penial morphology, on the other hand, is Leiobunum-like and the stylus tip also resembles that of Leiobunum. 
However, in most species of Leiobunum, the ventral membranes of the pockets are proximally attached to the dorsal membranes rather than distally, such as in Leiolima gen. nov.

Although many parts of the Iberian Peninsula have been poorly sampled, it is surprising that a relatively large species, with such an extended distribution area (19 localities within an area of approximately $30000 \mathrm{~km}^{2}$ ) and living in a common biotope, has been overlooked for such a long time.

\section{Acknowledgements}

This work was partially funded by the Basque Government through the Research Group on Systematics, Biogeography and Population Dynamics (GIC10/76; IT575/13) and by the Spanish Ministerio de Ciencia e Innovación (Ref. CGL2008-01131 / BOS). HW expresses his sincere gratitude towards the Uyttenboogaart-Eliasen Stichting for kindly awarding him with a grant (SUB.2012.05.04) to visit C. Prieto at the Basque University in Bilbao as part of a collecting expedition to Morocco and Spain. The text of the manuscript checked by Modern Manuscript Editing Services (http://www.mmanuscripteditserv.com/).

\section{References}

Burns M., Hedin M. \& Shultz J.W. 2012. Molecular phylogeny of the leiobunine harvestmen of eastern North America (Opiliones: Sclerosomatidae: Leiobuninae). Molecular Phylogenetics and Evolution 63 (2): 291-298. https://doi.org/10.1016/j.ympev.2011.12.025

Cokendolpher J.C. 1985. Revision of the harvestman genus Leptobunus and dismantlement of the Leptobunidae (Arachnida: Opiliones: Palpatores). Journal of the New York Entomological Society 92 (4) [1984]: 371-402.

Fernández R., Sharma P.P., Tourinho A.L. \& Giribet G. 2017. The Opiliones tree of life: shedding light on harvestmen relationships through transcriptomics. Proceedings of the Royal Society, B: Biological Sciences 284: e20162340. https://doi.org/10.1098/rspb.2016.2340

Gaona-Escamilla L., Francke O.F. \& Ponce-Saavedra J. 2016. El género Krusa (Opiliones: Sclerosomatidae: Gagrellinae) en México. Revista mexicana de Biodiversidad 87 (4): 1235-1256. https://doi.org/10.1016/j.rmb.2016.10.007

Hedin M., Tsurusaki N., Macías-Ordóñez R. \& Shultz J.W. 2012. Molecular systematics of sclerosomatid harvestmen (Opiliones, Phalangioidea, Sclerosomatidae): Geography is better than taxonomy in predicting phylogeny. Molecular Phylogenetics and Evolution 62: 224-236.

https://doi.org/10.1016/j.ympev.2011.09.017

Karaman I.M. 1996. A new Leiobunum species from Greece (Arachnida: Opiliones: Phalangiidae). Bulletin Zoölogisch Museum, Universiteit van Amsterdam 15 (5): 37-39.

Komposch C. 1998. Leiobunum subalpinum n. sp., ein neuer Weberknecht aus den Östalpen (Opiliones: Phalangiidae). Wissenschaftliche Mitteilungen aus dem Nationalpark Hohe Tauern 4: 19-40.

Kurt K. 2018. A new species of the genus Microliobunum from Turkey (Opiliones, Sclerosomatidae). Turkish Journal of Zoology 42 (4): 389-393. https://doi.org/10.3906/zoo-1710-26

Martens J. 1969. Mittel- und südeuropäische Arten der Gattung Nelima (Arachnida: Opiliones: Leiobunidae). Senckenbergiana Biologica 50 (5/6): 395-415.

Martens J. 1978. Spinnentiere, Arachnida: Weberknechte, Opiliones. Die Tierwelt Deutschlands 64. VEB G. Fischer, Jena.

Martens J. 1987. Opiliones aus dem Nepal-Himalaya. VI. Gagrellinae (Arachnida: Phalangiidae). Courier Forschungsinstitut Senckenberg 93: 87-202. 
Prieto C.E. \& Wijnhoven H., Leiolima (Opiliones, Sclerosomatidae), a new genus from Iberia

Martens J. \& Schönhofer A.L. 2016. The Leiobunum rupestre species group: resolving the taxonomy of four widespread European taxa (Opiliones: Sclerosomatidae). European Journal of Taxonomy 216: 1-35. https://doi.org/10.5852/ejt.2016.216

Palencia L., Peñalver E., Prieto C.E. \& Poyato-Ariza F.J. 2019. First fossil harvestmen (Arachnida: Opiliones) from Spain and notes on the fossil record of Opiliones. Palaeontologia Electronica 22.1.5A: 1-18. https://doi.org/10.26879/855

Prieto C.E. 2003. Primera actualización de la check-list de los Opiliones de la Península Ibérica e Islas Baleares. Revista ibérica de Aracnología 8: 125-141.

Prieto C.E. 2008. Updating the checklist of the Iberian opiliofauna: corrections, suppressions and additions. Revista Ibérica de Aracnología 16: 49-65.

Prieto C.E. \& Fernández J. 2007. El género Leiobunum C.L. Koch, 1839 (Opiliones: Eupnoi: Sclerosomatidae) en la Península Ibérica y el norte de África, con la descripción de tres nuevas especies. Revista ibérica de Aracnología 14: 135-171.

Prieto C.E. \& Wijnhoven H. 2017. A new Leiobunum species from the Iberian Peninsula (Opiliones: Sclerosomatidae: Leiobuninae). Revista ibérica de Aracnología 30: 3-10.

Rambla M. 1970. Contribución al estudio de los Opiliones de la fauna ibérica. La especie Cosmobunus granarius (Lucas, 1847) en la Península Ibérica y Norte de Africa. Publicaciones del Instituto de Biología aplicada (Barcelona) 48: 81-105.

Roewer C.F. 1923. Die Weberknechte der Erde, Systematische Bearbeitung der bisher bekannten Opiliones. Gustav Fischer, Jena.

Roewer C.F. 1952. Die Solifugen und Opilioniden der österreichischen Iran-Expedition 1949-1950. Sitzungsberichte und Anzeiger der Österreichische Akademie der Wissenschaften, MathematischNaturwissenschaftliche Klasse, Abteilung I, Biologische Wissenschaften und Erdwissenschaften 161 (7): 509-516.

Roewer C.F. 1957. Über Oligolophinae, Caddoinae, Sclerosomatinae, Leiobuninae, Neopilioninae und Leptobuninae (Phalangiidae, Opiliones Palpatores). Weitere Weberknechte XX. Senckenbergiana Biologica 38 (5/6): 323-358.

Shultz J.W. 2018. A new species of Leiobunum from Arizona, USA highlights the limits of typological classification in harvestmen (Opiliones: Sclerosomatidae: Leiobuninae). Zootaxa 4370 (1): 67-75.

https://doi.org/10.11646/zootaxa.4370.1.5

Šilhavý V. 1965. Die Weberknechte der Unterordnung Eupnoi aus Bulgarien; zugleich eine Revision europäischer Gattungen der Unterfamilien Oligolophinae und Phalangiinae (Arachnoidea, Opilionidea). Ergebnisse der zoologischen Expedition des Tschechoslowakischen Akademie der Wissenschaften nach Bulgarien im Jahre 1957 (Teil V). Acta Entomologica Bohemoslovaca 62 (5): 369-406.

Snegovaya N.Y., Cokendolpher J.C. \& Mozaffarian F. 2018. The Opiliones of Iran with a description of a new genus and two new species. Journal of Arachnology 46 (1): 69-80.

https://doi.org/10.1636/JoA-S-17-016.1

Staręga W. 1972. Revision der Phalangiidae (Opiliones), I. Gattung Bunochelis Roewer, 1923. Annales Zoologici 29 (14): 461-471.

Tsurusaki N. 2007. Phalangiidae Latreille, 1802. In: Pinto-da-Rocha R., Machado G. \& Giribet G. (eds) Harvestmen. The Biology of Opiliones: 123-126. Harvard Press, Cambridge.

Wijnhoven H. 2011. Notes on the biology of the unidentified invasive harvestman Leiobunum sp. (Arachnida: Opiliones). Arachnologische Mitteilungen 41: 17-30. 
Wijnhoven H. 2013. Sensory structures and sexual dimorphism in the harvestman Dicranopalpus ramosus (Arachnida: Opiliones). Arachnologische Mitteilungen 46: 27-46.

Wijnhoven H., Schönhofer A. \& Martens J. 2007. An unidentified harvestman Leiobunum sp. alarmingly invading Europe (Opiliones). Arachnologische Mitteilungen 34: 27-38.

Willemart R.H., Farine J.-P. \& Gnaspini P. 2009. Sensory biology of Phalangida harvestmen (Arachnida, Opiliones): a review, with new morphological data on 18 species. Acta Zoologica 90 (3): 209-227. https://doi.org/10.1111/j.1463-6395.2008.00341.x

Manuscript received: 25 April 2019

Manuscript accepted: 18 November 2019

Published on: 27 February 2020

Topic editor: Rudy Jocqé

Desk editor: Eva-Maria Levermann

Printed versions of all papers are also deposited in the libraries of the institutes that are members of the EJT consortium: Muséum national d'histoire naturelle, Paris, France; Meise Botanic Garden, Belgium; Royal Museum for Central Africa, Tervuren, Belgium; Royal Belgian Institute of Natural Sciences, Brussels, Belgium; Natural History Museum of Denmark, Copenhagen, Denmark; Naturalis Biodiversity Center, Leiden, the Netherlands; Museo Nacional de Ciencias Naturales-CSIC, Madrid, Spain; Real Jardín Botánico de Madrid CSIC, Spain; Zoological Research Museum Alexander Koenig, Bonn, Germany; National Museum, Prague, Czech Republic. 